\title{
Annual Elections
}

\section{Honorary Officers}

Fellows and Members of the College are reminded of their rights in connection with the forthcoming elections for the offices of Dean, Registrar, Treasurer, Editor and Librarian. All Honorary Officers are eligible for re-election.

The nominating meeting of Council will be held on $18 \mathrm{March} 1992$, and the last date for receiving nominations will therefore be 15 April 1992. The relevant Bye-Laws and Regulations are printed below.

\section{Extracts from Bye-Laws and Regulations}

Bye-Law XII THE OTHER HONORARY OFFICERS

1. The Council shall, in accordance with the Regulations, make its nominations for the offices of Dean, Registrar, Treasurer, Editor, Librarian at the first meeting after the name of the President for the next ensuing College year has become known. Written nominations for the above Honorary Offices, accompanied in each case by the nominee's written consent to stand for election, may also be lodged with the Registrar at such time as may be prescribed by the Regulations, provided that each such nomination is supported in writing by not less than twelve Members of the College who are not members of the council.

2. The Dean, Registrar, Treasurer, Editor and Librarian shall be elected from amongst the Fellows by the Members of the College, in each case in accordance with the procedure prescribed by the Regulations.

\section{Regulation XII ELECTION OF THE OTHER HONORARY} OFFICERS

1. The method of electing the Honorary Officers other than the President and the Vice-Presidents and Sub-Deans shall be the same as that for electing the President, * save that nominations from Members of the College who are not members of the Council shall be lodged with the Registrar between the first day of January in any calendar year and the date which is four clear weeks after that meeting of the Council which is first held after the name of the President for the next ensuing College year has become known, or (as the case may be) which is four clear weeks after that meeting of the Council which, in the case of a tie on the second ballot, determines the election of the President.

*i.e. Written nominations, accompanied in each case by the nominee's written consent to stand for election, may be lodged with the Registrar, provided that each such nomination is supported in writing by not less than twelve Members of the College who are not members of the Council. An election by ballot shall be held in accordance with the provisions of the Regulations. 